\title{
High Performance Window Retrofit
}

\section{December 2013}

\section{Prepared by}

Som S. Shrestha

Diana E. Hun

Andre O. Desjarlais 


\section{DOCUMENT AVAILABILITY}

Reports produced after January 1, 1996, are generally available free via the U.S. Department of Energy (DOE) Information Bridge.

Web site http://www.osti.gov/bridge

Reports produced before January 1, 1996, may be purchased by members of the public from the following source.

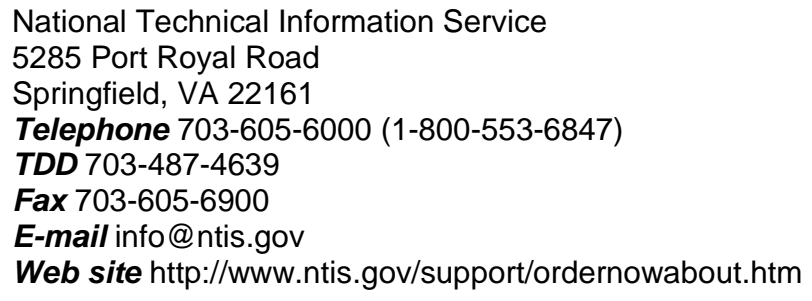

Reports are available to DOE employees, DOE contractors, Energy Technology Data Exchange (ETDE) representatives, and International Nuclear Information System (INIS) representatives from the following source.

Office of Scientific and Technical Information

P.O. Box 62

Oak Ridge, TN 37831

Telephone 865-576-8401

Fax 865-576-5728

E-mail reports@osti.gov

Web site http://www.osti.gov/contact.html

This report was prepared as an account of work sponsored by an agency of the United States Government. Neither the United States Government nor any agency thereof, nor any of their employees, makes any warranty, express or implied, or assumes any legal liability or responsibility for the accuracy, completeness, or usefulness of any information, apparatus, product, or process disclosed, or represents that its use would not infringe privately owned rights. Reference herein to any specific commercial product, process, or service by trade name, trademark, manufacturer, or otherwise, does not necessarily constitute or imply its endorsement, recommendation, or favoring by the United States Government or any agency thereof. The views and opinions of authors expressed herein do not necessarily state or reflect those of the United States Government or any agency thereof. 


\section{High Performance Window Retrofit}

Som S. Shrestha

Diana E. Hun

Andre O. Desjarlais

Date Published: November 2013

Prepared by

OAK RIDGE NATIONAL LABORATORY

Oak Ridge, Tennessee 37831-6283

managed by

UT-BATTELLE, LLC

for the

U.S. DEPARTMENT OF ENERGY

under contract DE-AC05-00OR22725 


\section{Content}

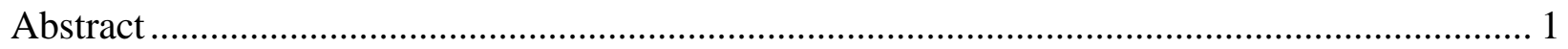

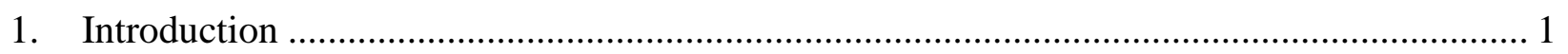

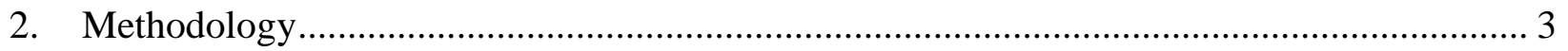

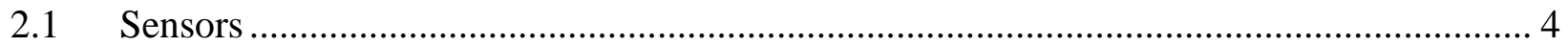

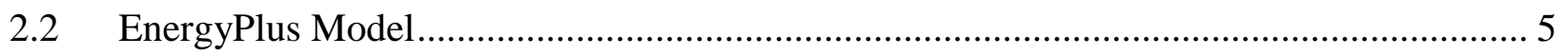

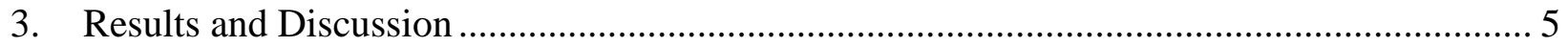

3.1 Baseline Window Properties................................................................................... 5

3.2 Field Measured Data ........................................................................................... 7

3.3 Comparison between Field Measured Data and EnergyPlus Simulation Results............... 7

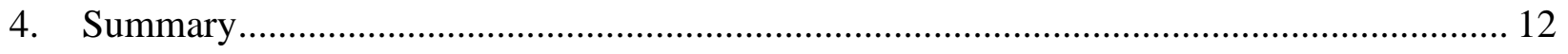

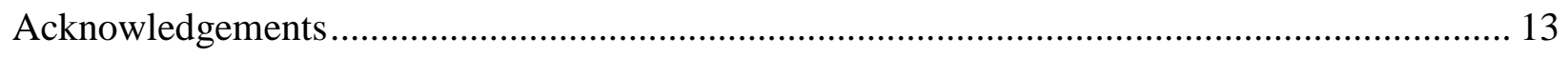

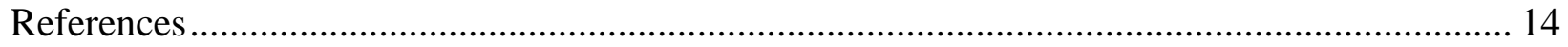

\section{List of Figures}

Figure 1. Renderings of the Flexible Research Platforms. Top: permanent structures. Bottom:

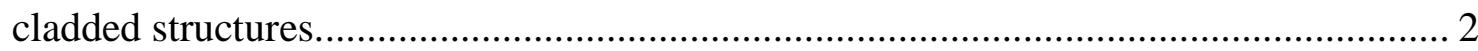

Figure 2. Flexible Research Platforms cladded to emulate 1980s metal buildings (left) and office buildings from the 10-county Greater Philadelphia region (right). .............................. 2

Figure 3. Traco's OptiQ ${ }^{\mathrm{TM}}$ Ultra Thermal windows......................................................... 3

Figure 4. Weather station and windows performance evaluation sensors. ............................... 4

Figure 5. Rendering of the EnergyPlus model of the two-story FRP building............................ 5

Figure 6. Dimensions of the baseline windows. ................................................................. 6

Figure 7. Comparison of direct beam radiation measured at the two-story Flexible Research Platform and estimated with the ASHRAE clear sky model. ...................................... 7

Figure 8. Comparison between measured and EnergyPlus predicted transmitted solar radiation through the east-facing window............................................................................ 8

Figure 9. Comparison between measured and EnergyPlus predicted transmitted solar radiation through the south-facing window.

Figure 10. Comparison between measured and EnergyPlus predicted transmitted solar radiation through the west-facing window. 
Figure 11. Comparison between measured and EnergyPlus predicted glass surface temperature at the east-facing window.

Figure 12. Comparison between measured and EnergyPlus predicted glass surface temperature at the south-facing window............................................................................................. 10

Figure 13. Comparison between measured and EnergyPlus predicted glass surface temperature

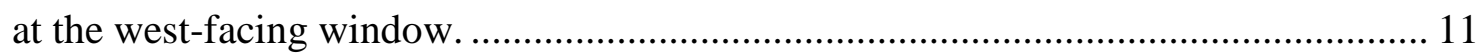

Figure 14. Net heat gain rate through windows......................................................................... 12

Figure 15. EnergyPlus predicted monthly net heat gain rate through windows.......................... 12

\section{List of Tables}

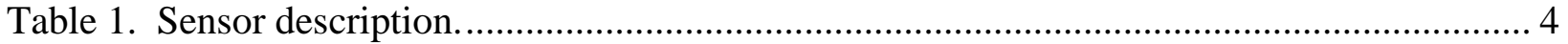

Table 2. Measured properties of the baseline window glazing....................................................... 6

Table 3. Difference between measured and EnergyPlus predicted transmitted solar radiation, $\mathrm{W} / \mathrm{m}^{2}$

Table 4. Difference between measured and EnergyPlus predicted glass surface temperature, ${ }^{\circ} \mathrm{F} 11$ 


\section{Abstract}

The US Department of Energy (DOE) Office of Energy Efficiency and Renewable Energy (EERE) and Traco partnered to develop high-performance windows for commercial building that are cost-effective. The main performance requirement for these windows was that they needed to have an R-value of at least $5 \mathrm{ft}^{2} \cdot \mathrm{F} \cdot \mathrm{h} / \mathrm{Btu}$. This project seeks to quantify the potential energy savings from installing these windows in commercial buildings that are at least 20 years old. To this end, we are conducting evaluations at a two-story test facility that is representative of a commercial building from the 1980s, and are gathering measurements on the performance of its windows before and after double-pane, clear-glazed units are upgraded with R5 windows. Additionally, we will use these data to calibrate EnergyPlus models that we will allow us to extrapolate results to other climates. Findings from this project will provide empirical data on the benefits from high-performance windows, which will help promote their adoption in new and existing commercial buildings. This report describes the experimental setup, and includes some of the field and simulation results.

\section{Introduction}

Buildings consume approximately 40\% of the energy used in the US. According to the 2003 Commercial Buildings Energy Consumption Survey (US Energy Information Administration 2003), light commercial buildings, which are defined in this report as structures with a floor area less than $50,000 \mathrm{ft}^{2}$, are responsible for about $20 \%$ of this energy usage. Given that nearly $70 \%$ of these buildings are at least 20 years old, their building envelopes likely have:

- Minimal or no thermal insulation

- High air leakage rates

- Clear-glazed, single-pane windows

Therefore, there is ample opportunity to improve the energy efficiency of light commercial structures by retrofitting their envelopes.

The Building Technology Research and Integration Center (BTRIC) at Oak Ridge National Laboratory (ORNL) has the expertise and facilities to assess the effectiveness of retrofitting techniques that are suitable for commercial buildings. In 2013, the Flexible Research Platforms (FRPs) were completed at the ORNL campus. These facilities consist of permanent structures where different building envelopes, as well as various heating, ventilation, and air conditioning (HVAC) systems can be evaluated while being subjected to natural environmental conditions (Figure 1). The one-story platform has a $40^{\prime} \times 60^{\prime}$ footprint, and the two-story structure covers a $40^{\prime} \times 40^{\prime}$ area. In order to expand the capabilities of these facilities, both FRPs have "active foundations" that can thermally isolate the buildings from the ground. A more detailed description of these platforms is provided by Hughes (2012). 


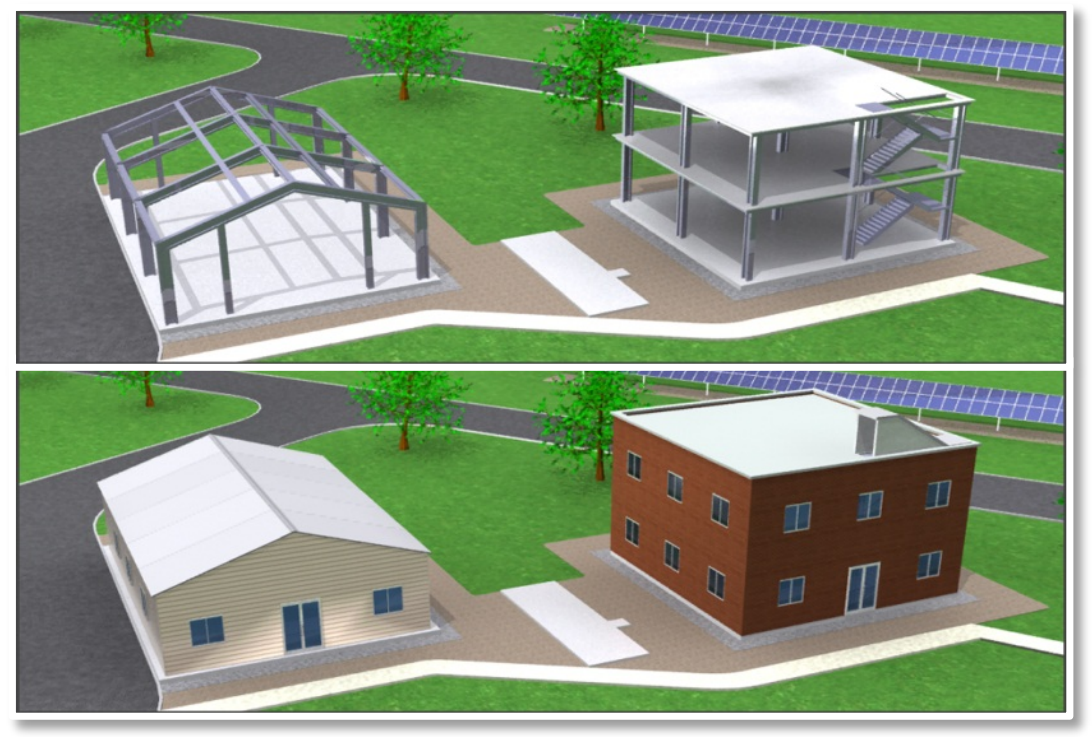

Figure 1. Renderings of the Flexible Research Platforms. Top: permanent structures. Bottom: cladded structures.

Current research at the FRPs focuses on how to effectively retrofit buildings from the 1980s (Figure 2). Work at the one-story FRP aims to improve the energy efficiency of metal buildings given that metal buildings account for about $40 \%$ of the nation's light commercial building construction based on floor area. The two-story FRP presently simulates commercial buildings from the 10-county Greater Philadelphia region, which are primarily steel structures with brick facades over masonry walls. The collection of 12-month baseline data was initiated in the summer of 2013; afterwards, various retrofitting techniques will be studied in detail.
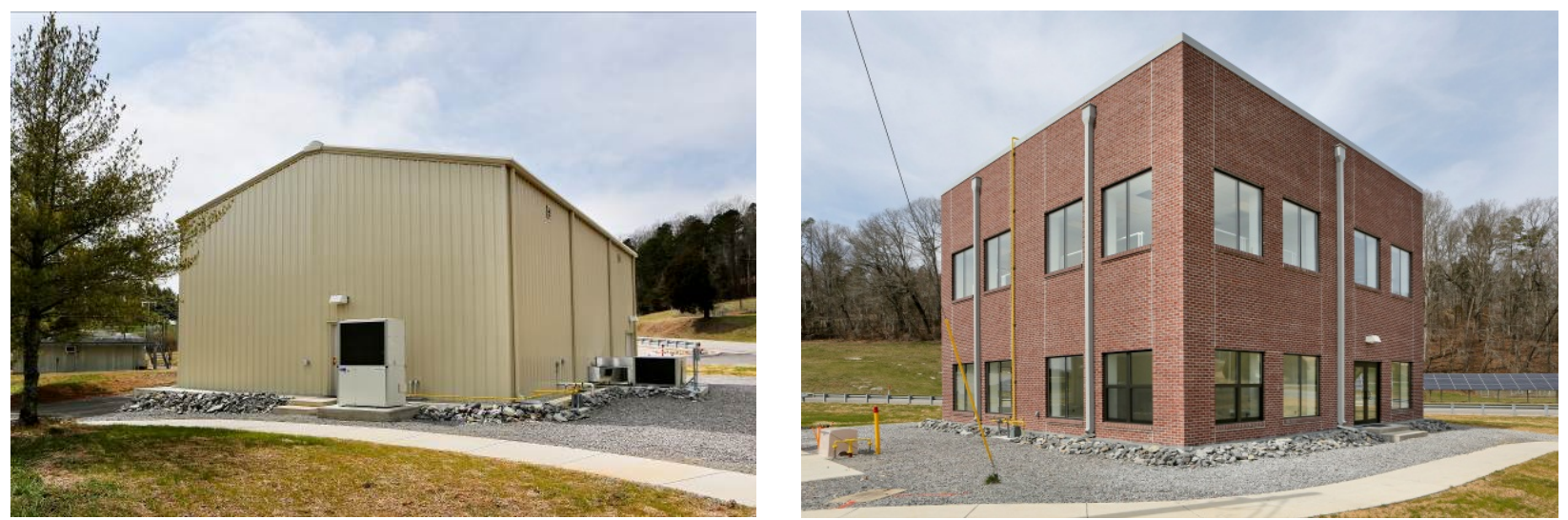

Figure 2. Flexible Research Platforms cladded to emulate 1980s metal buildings (left) and office buildings from the 10-county Greater Philadelphia region (right).

One of the first retrofits that will take place in the two-story FRP is to upgrade the baseline windows. This effort is a continuation of the project "R5 Commercial Windows" where the Department of Energy and Traco partnered to develop cost-effective, high-performance windows 
for commercial buildings. DOE's interest in windows is based on computer simulations that indicate that heat losses through these units account for approximately $22 \%$ of the heating loads in commercial buildings (Huang and Franconi 1999). The present project seeks to use data from the 2 story FRP to quantify the potential energy savings from changing double-pane, clear-glazed units (R-value $=2 \mathrm{ft}^{2} \cdot \mathrm{F} \cdot \mathrm{h} / \mathrm{Btu}$ ) with Traco's OptiQTM Ultra Thermal windows (Figure 3) that have an R-value of $5 \mathrm{ft}^{2} \cdot \mathrm{F} \cdot \mathrm{h} / \mathrm{Btu}$ due to triple glazing and insulated framing. To this end, we will gather measurements before and after the retrofit. Furthermore, we will use these data to calibrate EnergyPlus models that will allow us to extrapolate our findings to other climates. In this report we describe the experimental setup, include a sample of the data collected thus far, and show how the field measurements compare to results from our simulations.

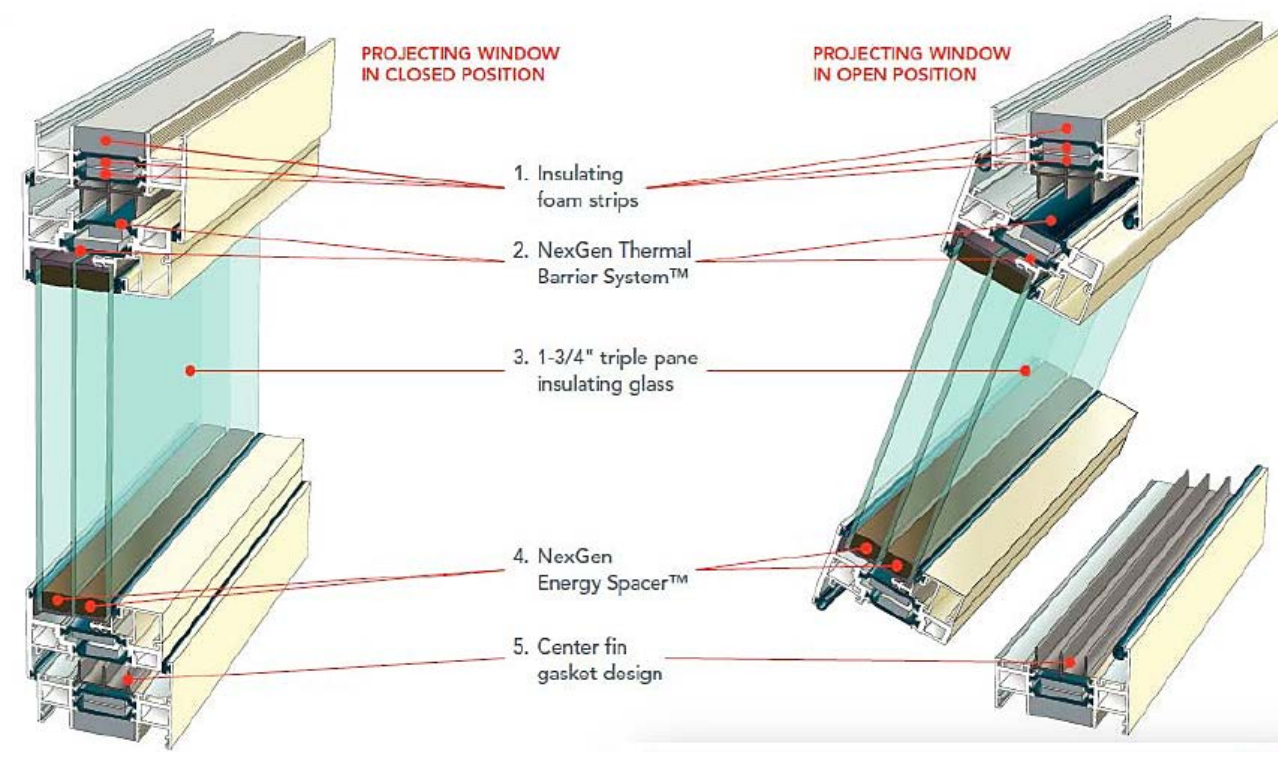

Figure 3. Traco's OptiQ ${ }^{\mathrm{TM}}$ Ultra Thermal windows (Source: http://www.kawneer.com/kawneer/north america/en/product.asp?prod id=4306).

\section{Methodology}

The performance of the baseline windows is being evaluated by monitoring a few key parameters. Solar radiation transmitted through windows to the conditioned space is being measured with precision spectral pyranometers installed on the east, south, and west facing units. In order to calculate convection and radiation heat exchanges between the windows and the indoor space, temperature measurements are being collected at the center of the glass, glass temperatures at $6 \mathrm{~cm}$ from the window frame, the window frame and the temperature of each room.

A weather station sits on the roof of the two-story FRP. The station measures the following radiation parameters: direct beam radiation, global horizontal radiation, and infrared radiation from the sky. Other outdoor parameters being monitored include barometric pressure, wind speed and direction, rainfall, air temperature, and relative humidity. EnergyPlus weather file 
(epw) was created using data from the weather station. The epw file was used to run EnergyPlus to benchmark simulation results against field-measured data, and to predict net heat gain/loss through windows.

\subsection{Sensors}

Table 1 describes the sensors being used at the FRPs. Figure 4 shows some of the instruments installed at FRP.

Table 1. Sensor description.

\begin{tabular}{lcc}
\hline \multicolumn{1}{c}{ Parameter } & Manufacturer & Sensor Model \\
\hline Wall panels and indoors & & \\
\hline Temperature & Honeywell/Fenwal & 192-103LET-A01 \\
Relative humidity & Honeywell & HIH-4000 \\
Heat flux & Concept Engineering & F-002-4 \\
Transmitted solar radiation through windows & Eppley & PSP \\
Pressure & Energy Conservatory & APT \\
\hline Weather station & & \\
\hline Temperature & Campbell Scientific & CS215 \\
Relative humidity & Campbell Scientific & CS215 \\
Wind speed/direction & Gill & WindSonic \\
Rainfall & Texas Electronics & TE525WS \\
Global Horizontal solar radiation & LI-COR & LI-200X \\
Direct beam radiation & Eppley & NIP \\
IR radiation from sky & Eppley & PIR \\
Solar radiation on vertical surfaces & Campbell Scientific & LI-200X \\
Atmospheric pressure & Vaisala & CS106 \\
\hline
\end{tabular}

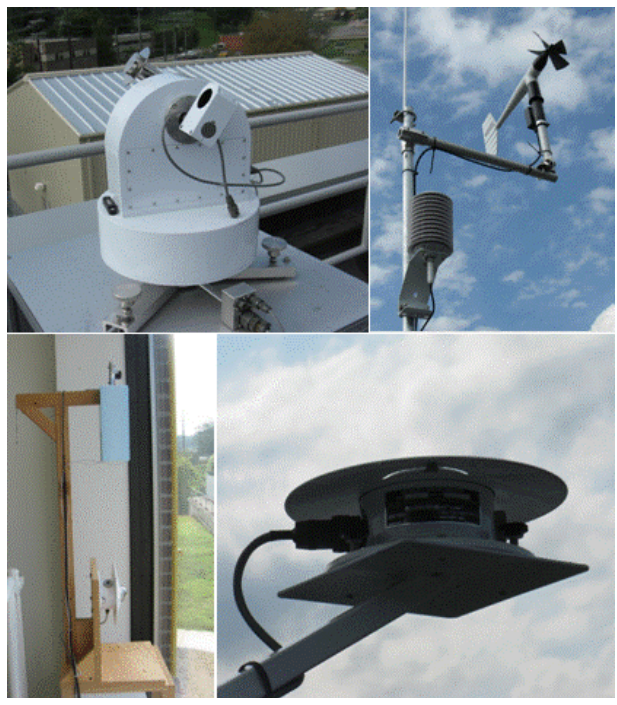

Figure 4. Weather station and windows performance evaluation sensors. 


\subsection{EnergyPlus Model}

An EnergyPlus model of the two-story FRP building was developed using actual construction details. Important parameters such as the location and properties of windows were verified with field measurements. The "WindowMaterial:SimpleGlazingSystem" option was used to model the windows in EnergyPlus. Figure 5 shows a rendering of the EnergyPlus model of the building. The building has window-to-wall ratios of about $27 \%$.

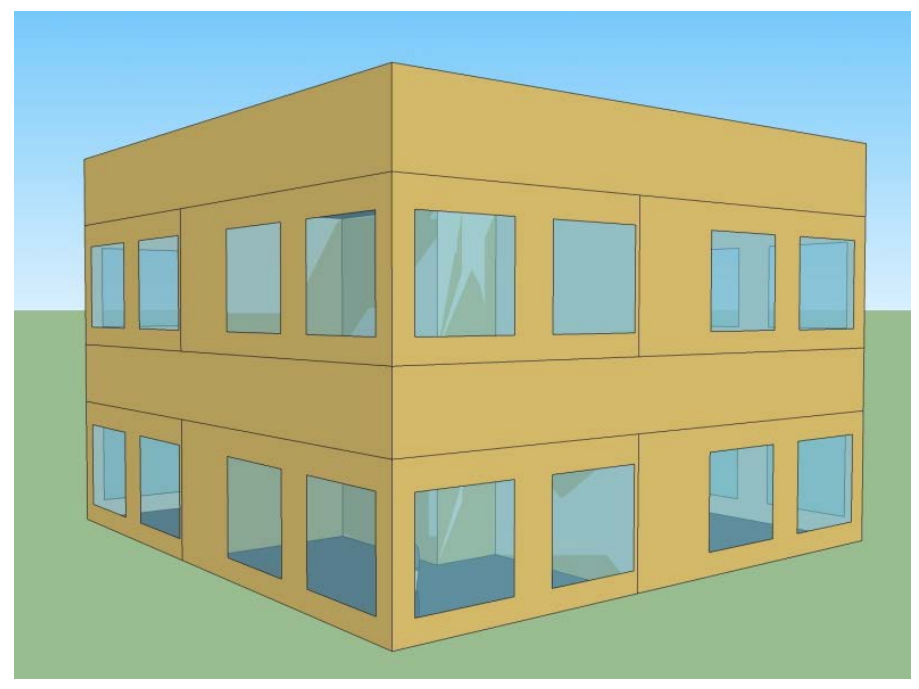

Figure 5. Rendering of the EnergyPlus model of the two-story FRP building.

\section{Results and Discussion}

\subsection{Baseline Window Properties}

The installed baseline windows have a thermally-broken aluminum frame and two layers of clear glass with $1 / 2$ " air gap between panes. The solar transmittance and solar heat gain coefficient (SHGC) of the glazing was measured using the EDTM Window Energy Profiler. Figure 6 shows the dimensions of the baseline windows and Table 2 lists the measured properties at four sides of the windows (M1 to M4) and their average values. 


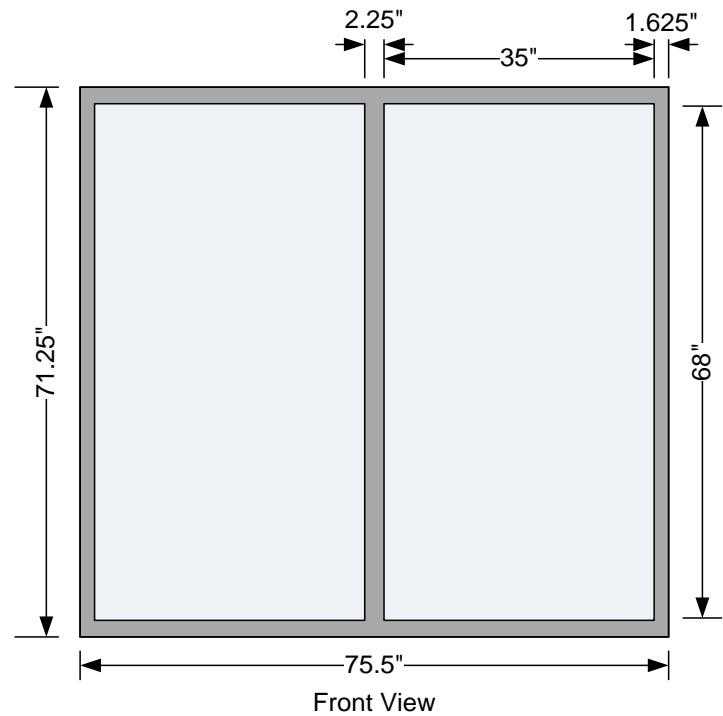

Figure 6. Dimensions of the baseline windows.

Table 2. Measured properties of the baseline window glazing.

\begin{tabular}{|c|c|c|c|c|c|}
\hline Location & Measurement & $\begin{array}{c}\text { UV (A) } \\
(<400 \mathrm{~nm}) \\
\text { Transmittance }\end{array}$ & $\begin{array}{c}\text { Visible } \\
(400-700 \mathrm{~nm}) \\
\text { Transmittance }\end{array}$ & $\begin{array}{l}\text { Near Infrared } \\
\text { (> } 700 \mathrm{~nm}) \\
\text { Transmittance }\end{array}$ & $\begin{array}{c}\text { Estimated } \\
\text { SHGC }\end{array}$ \\
\hline \multirow{5}{*}{ Stairwell } & M1 & 0.53 & 0.79 & 0.65 & 0.78 \\
\hline & $\mathrm{M} 2$ & 0.53 & 0.79 & 0.65 & 0.78 \\
\hline & M3 & 0.53 & 0.79 & 0.66 & 0.78 \\
\hline & M4 & 0.52 & 0.79 & 0.66 & 0.78 \\
\hline & Average & 0.53 & 0.79 & 0.66 & 0.78 \\
\hline \multirow{5}{*}{ North Room } & M1 & $\overline{0.52}$ & 0.79 & $\overline{0.66}$ & 0.78 \\
\hline & $\mathrm{M} 2$ & 0.53 & 0.79 & 0.66 & 0.78 \\
\hline & M3 & 0.53 & 0.80 & 0.66 & 0.78 \\
\hline & M4 & 0.53 & 0.79 & 0.65 & 0.78 \\
\hline & Average & 0.53 & 0.79 & 0.66 & 0.78 \\
\hline \multirow{4}{*}{$\begin{array}{l}\text { North-West } \\
\text { Room }\end{array}$} & M1 & $\overline{0.54}$ & $\overline{0.80}$ & $\overline{0.65}$ & $\overline{0.78}$ \\
\hline & $\mathrm{M} 2$ & 0.51 & 0.79 & 0.65 & 0.78 \\
\hline & $\mathrm{M} 3$ & 0.52 & 0.80 & 0.65 & 0.78 \\
\hline & Average & $\underline{0.52}$ & 0.80 & 0.65 & $\underline{0.78}$ \\
\hline \multirow{5}{*}{$\begin{array}{l}\text { South-West } \\
\text { Room }\end{array}$} & M1 & $\overline{0.53}$ & $\overline{0.79}$ & $\overline{0.65}$ & $\overline{0.78}$ \\
\hline & M2 & 0.53 & 0.79 & 0.65 & 0.78 \\
\hline & $\mathrm{M} 3$ & 0.53 & 0.80 & 0.65 & 0.78 \\
\hline & M4 & 0.51 & 0.79 & 0.65 & 0.78 \\
\hline & Average & 0.53 & 0.79 & 0.65 & 0.78 \\
\hline \multirow{5}{*}{$\begin{array}{l}\text { South-East } \\
\text { Room }\end{array}$} & M1 & $\overline{0.52}$ & $\overline{0.79}$ & $\overline{0.65}$ & $\overline{0.78}$ \\
\hline & $\mathrm{M} 2$ & 0.51 & 0.79 & 0.65 & 0.78 \\
\hline & $\mathrm{M} 3$ & 0.53 & 0.80 & 0.65 & 0.78 \\
\hline & M4 & 0.54 & 0.80 & 0.65 & 0.78 \\
\hline & Average & 0.53 & 0.80 & $\underline{0.65}$ & 0.78 \\
\hline
\end{tabular}




\subsection{Field Measured Data}

The accuracy of measured solar data from the weather station is an important parameter required by EnergyPlus to predict solar radiation transmitted through windows. To assure that the measured solar radiation was reasonable, the field measured data were compared to solar radiation predictions from the ASHRAE clear sky model during a fairly clear sky day in September. Figure 7 compares the measured direct beam solar radiation to the model predicted values. The measured data matched fairly well with the model predicted values. However, early morning and late evening measurements were cutoff because of shadows casted by small hills on east and north-west side of the building.

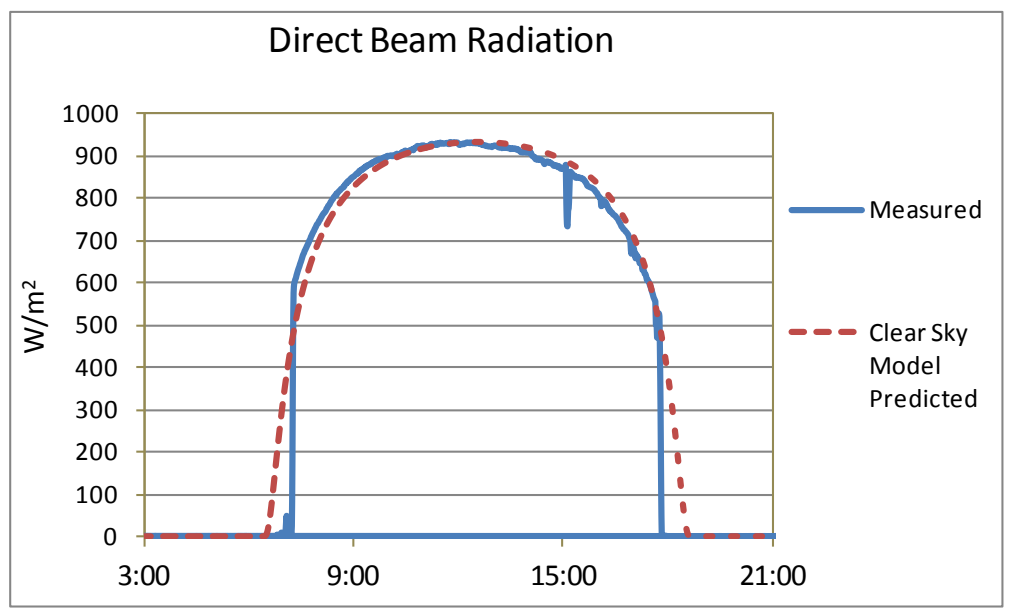

Figure 7. Comparison of direct beam radiation measured at the two-story Flexible Research Platform and estimated with the ASHRAE clear sky model.

\subsection{Comparison between Field Measured Data and EnergyPlus Simulation Results}

Figures 8 to 10 compare measured transmitted solar radiation through east, south, and westfacing windows with EnergyPlus predicted values during two days in September. The two days were selected such that one day had fairly clear sky condition (first day) and another day was partly cloudy (second day). Table 3 presents the maximum, minimum, and average difference between measured and EnergyPlus predicted hourly transmitted solar radiation through windows. Only the data from dawn to dusk (6:00 am to 7:00 pm) was used for this analysis. Even though the average difference is fairly low, the maximum differences were significantly high at some hours. In general, EnergyPlus predicted values were higher than measured values during morning hours and lower during noon and evening hours. Additionally, the measured and model predicted transmitted solar radiation were in better for agreement in the south window than in the east and west windows. As discussed earlier, "WindowMaterial:SimpleGlazingSystem" was used to model the windows in EnergyPlus. Reasons for the observed discrepancies will be explored as this study progresses. 


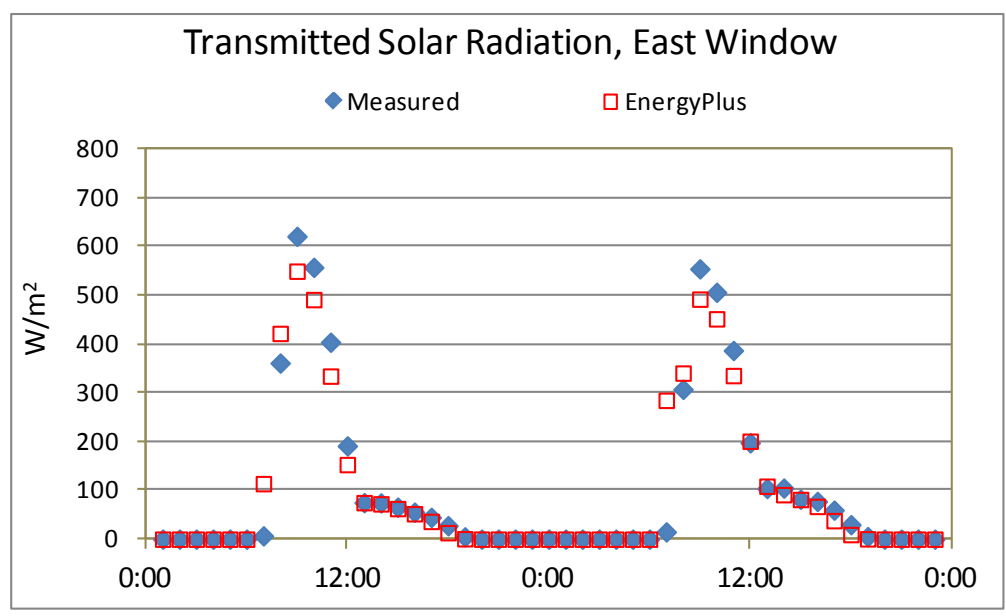

Figure 8. Comparison between measured and EnergyPlus predicted transmitted solar radiation through the east-facing window.

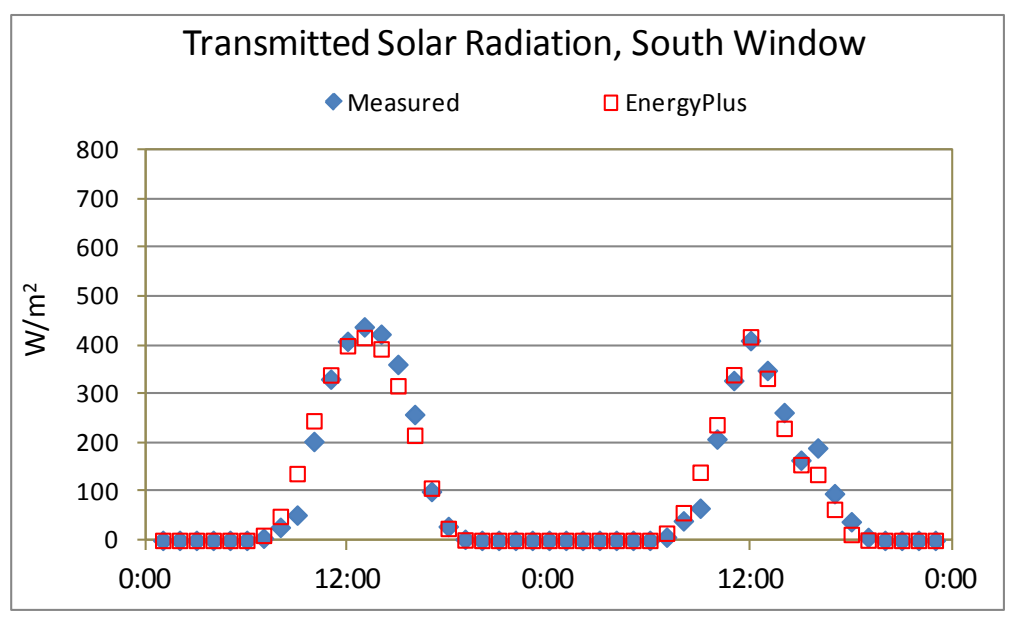

Figure 9. Comparison between measured and EnergyPlus predicted transmitted solar radiation through the south-facing window. 


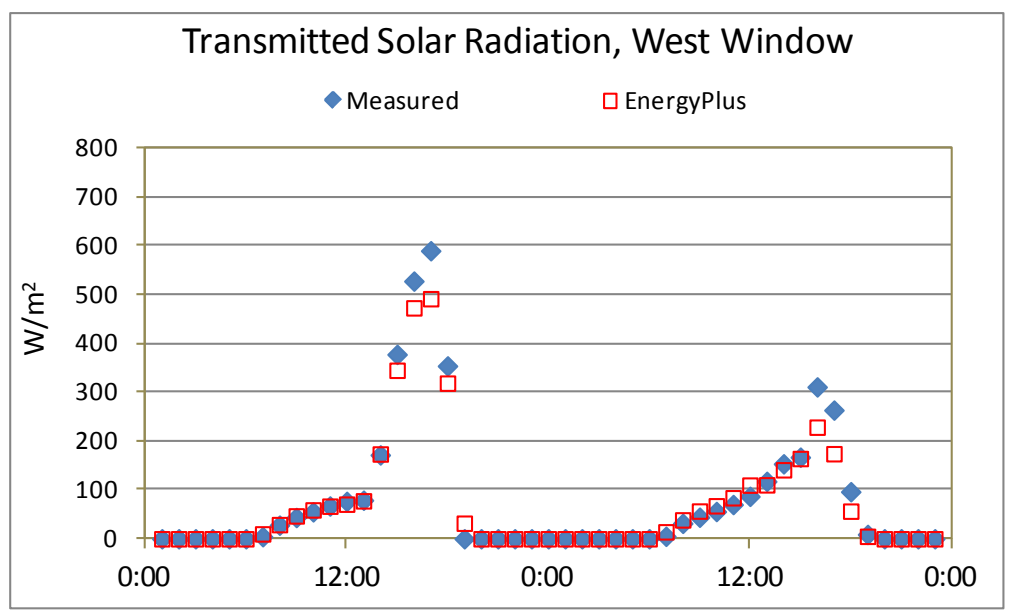

Figure 10. Comparison between measured and EnergyPlus predicted transmitted solar radiation through the west-facing window.

Table 3. Difference between measured and EnergyPlus predicted transmitted solar radiation, $\mathrm{W} / \mathrm{m}^{2}$.

\begin{tabular}{|l|c|c|c|}
\hline & Maximum & Minimum & Average \\
\hline \hline East Window & 71.3 & -269.7 & 1.5 \\
\hline South Window & 54.3 & -85.0 & 0.4 \\
\hline West Window & 98.2 & -31.9 & 13.1 \\
\hline
\end{tabular}

For the same two days in September, Figures 11 to 13 compare measured and model predicted temperatures of the indoor and outdoor center of the glass surfaces of the east, south, and westfacing windows. Table 4 presents the maximum, minimum, and average differences between measured and EnergyPlus predicted hourly surface temperatures. Results indicate that EnergyPlus predicted surface temperatures were higher than measured values, except for the outdoor surface measurements from the south-facing window. As noted earlier, reasons for the discrepancies will be examined in the near future. 


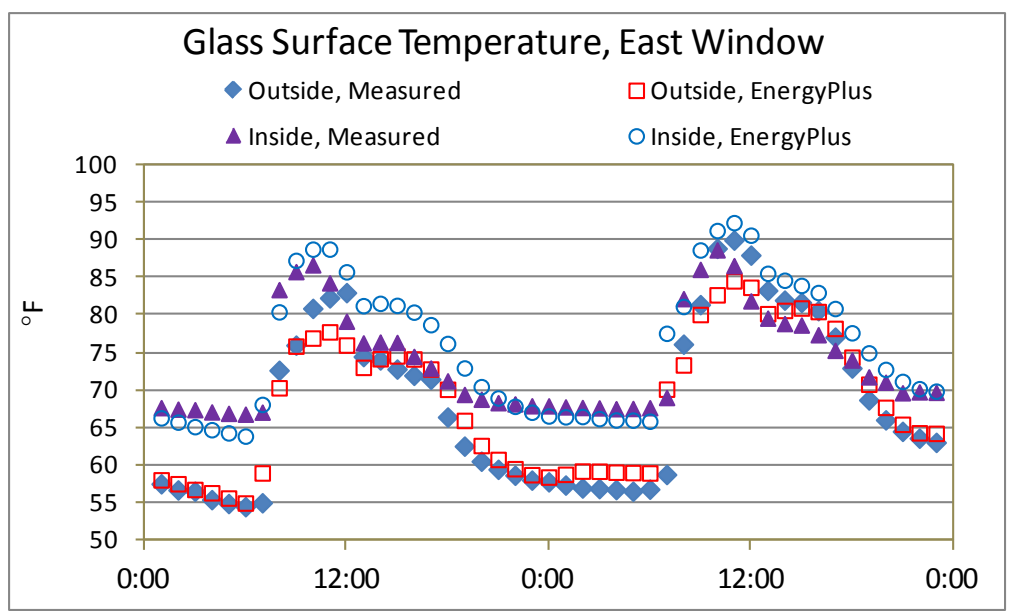

Figure 11. Comparison between measured and EnergyPlus predicted glass surface temperature at the east-facing window.

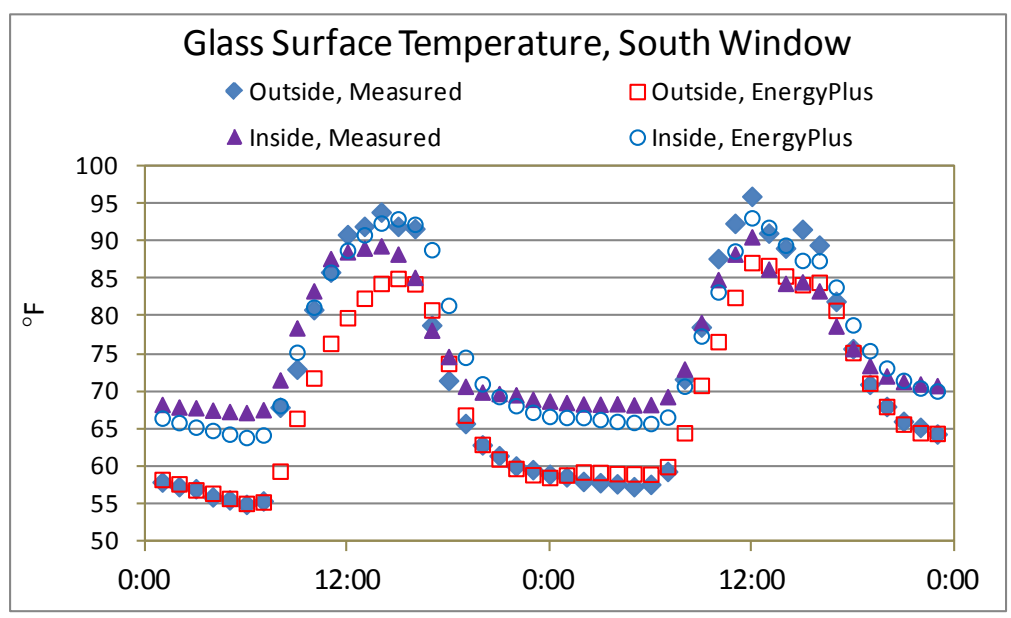

Figure 12. Comparison between measured and EnergyPlus predicted glass surface temperature at the south-facing window. 


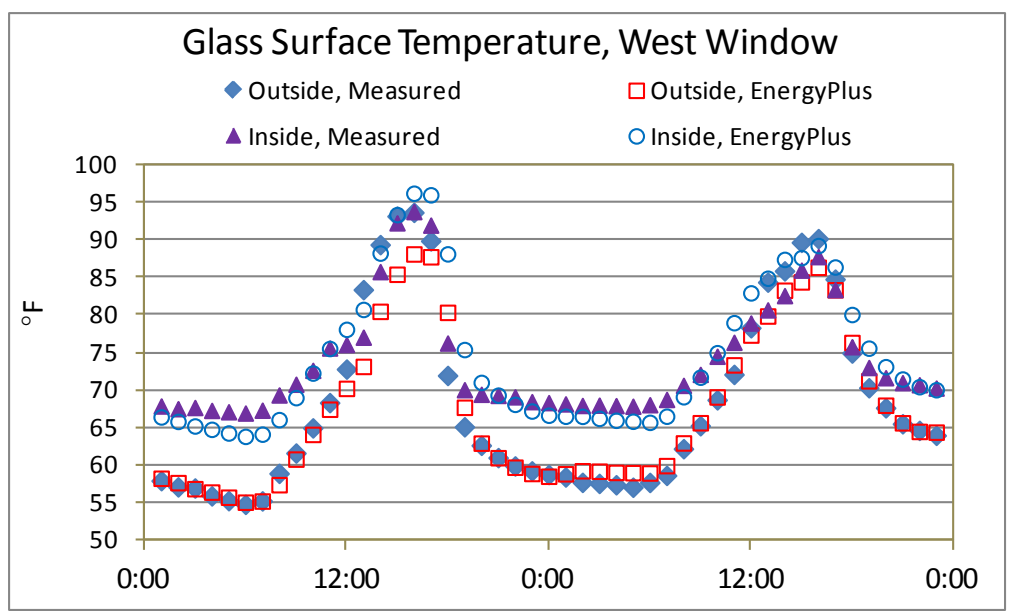

Figure 13. Comparison between measured and EnergyPlus predicted glass surface temperature at the west-facing window.

Table 4. Difference between measured and EnergyPlus predicted glass surface temperature, ${ }^{\circ} \mathrm{F}$

\begin{tabular}{|l|c|c|c|}
\hline & Maximum & Minimum & Average \\
\hline \hline East Facing, Indoor Side & 3.0 & -8.8 & -1.9 \\
\hline South Facing, Indoor Side & 3.4 & -10.7 & -0.3 \\
\hline West Facing, Indoor Side & 3.3 & -11.9 & -0.5 \\
\hline East Facing, Outdoor Side & 7.0 & -11.4 & -0.3 \\
\hline South Facing, Outdoor Side & 11.1 & -2.3 & 2.8 \\
\hline West Facing, Outdoor Side & 10.2 & -8.4 & 0.6 \\
\hline
\end{tabular}

For the same two days, Figure 14 shows the EnergyPlus predicted net heat gain rate through the windows. The net heat gain rate is calculated as the difference between window heat gain rate and heat loss rate for a given time interval. EnergyPlus considers window heat gain rate as the total heat flow to the conditioned space from the glazing, frame and divider of an exterior window when the total heat flow is positive. The opposite is true for the window heat loss. 


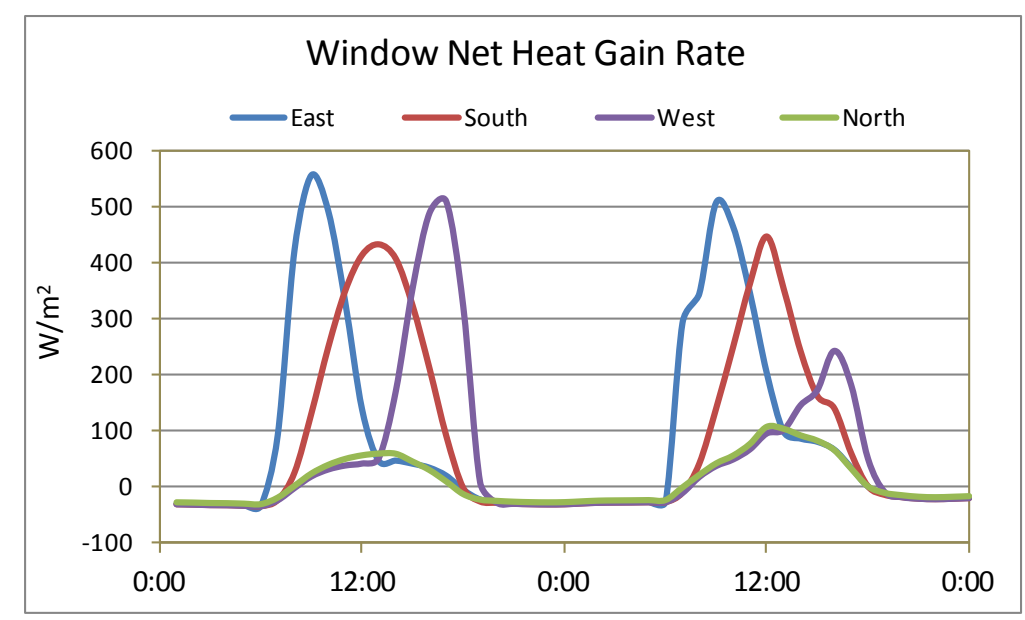

Figure 14. Net heat gain rate through windows.

Figure 15 shows the EnergyPlus calculated monthly net heat gain per unit area through the windows during August and September 2013. While the heat gain through the east and southfacing windows were greater during September compared to that during August, the opposite was true for the west and north-facing windows.

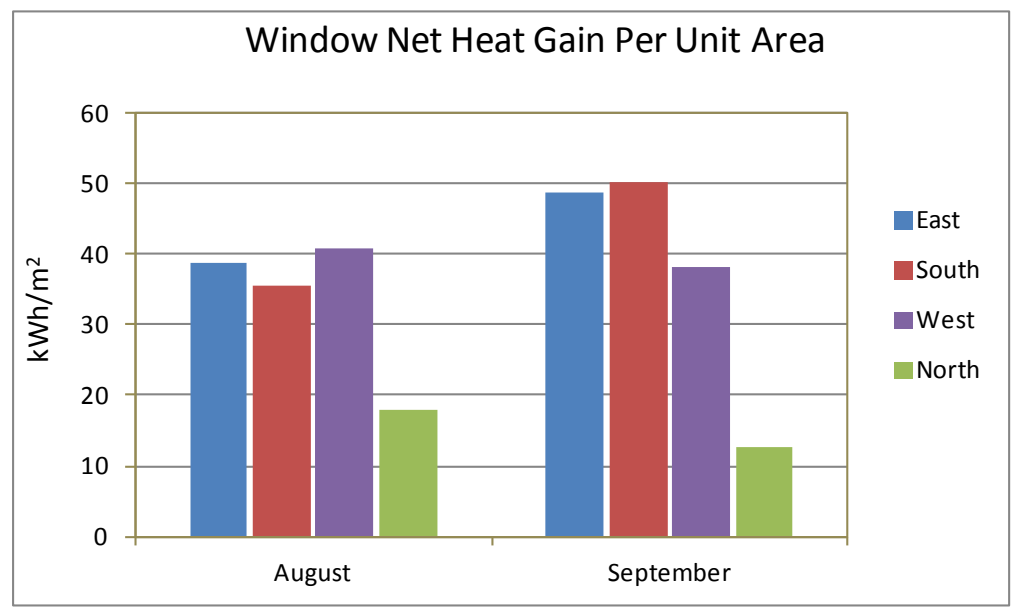

Figure 15. EnergyPlus predicted monthly net heat gain rate through windows.

\section{Summary}

This preliminary report describes the ongoing research at ORNL that intends to evaluate performance of high-performance R5 windows for commercial buildings that were developed by Traco with support from DOE, and to estimate potential energy savings from the usage of these 
windows in various climates. To that end, baseline windows with an R-value of $2 \mathrm{ft}^{2} \cdot \mathrm{F} \cdot \mathrm{h} / \mathrm{Btu}$ were installed at the two-story Flexible Research Platform building at ORNL, and their performance is being monitored. This report presents some of the data collected during August and September of 2013. EnergyPlus predicted transmitted solar radiation and glass surface temperatures were compared against the field measured data. Some discrepancies between the measured and EnergyPlus predicted values were noted. Reasons behind these differences will be assessed as this project continues. As a next step, a more detailed window model will be created in EnergyPlus that might reduce the observed discrepancies.

The baseline windows will be monitored for a year. Afterwards, these units will be replaced with R5 windows, and data will be collected for 12 months. The two-year database will be used to estimate the potential energy savings from the deployment of R5 windows to new and existing light commercial buildings. Results from this analysis will be strengthened by the fact that it will be based on empirical data. A final report will be issued summarizing all of these findings.

\section{Acknowledgements}

This work was supported by the Assistant Secretary for Energy Efficiency and Renewable Energy, Office of the Building Technology Program, U.S. Department of Energy, under Contract No. DE- AC05-00OR22725. 


\section{References}

Huang J, Franconi E. 1999. Commercial heating and cooling loads component analysis. Lawrence Berkeley National Laboratory. LBNL 37208.

Hughes P. 2012. Light Commercial Building Flexible Research Platforms. Oak Ridge National Laboratory. Report ORNL/TM-2012/143.

US Energy Information Administration. 2003. Commercial buildings energy consumption survey. http://www.eia.gov/consumption/commercial/. 